\title{
Search for polyisoprenoids in the flowers and fruits of selected coastal plants using two-dimensional thin layer chromatography
}

\author{
Mohammad Basyuni ${ }^{1,2, *}$, Ridha Wati ${ }^{1,2}$, Astrid Nur Prabuanisa ${ }^{1}$, I Komang Tri Wijaya Kusuma $^{3}$, Hamiuddin Hamiuddin ${ }^{4}$, \\ Guntur Guntur ${ }^{4}$, and Hiroshi Sagami ${ }^{5}$ \\ ${ }^{1}$ Department of Forestry, Faculty of Forestry, Universitas Sumatera Utara, J1. Tri Dharma Ujung No. 1 Medan 20155, Indonesia \\ ${ }^{2}$ Mangrove and Bio-Resources Group, Center of Excellence for Natural Resources Based Technology, Universitas Sumatera Utara, \\ Medan, North Sumatera 20155, Indonesia \\ ${ }^{3}$ Balai PPI dan Karhutla Wilayah Jawa Bali Nusra, Suwung Kauh, Denpasar, Indonesia \\ ${ }^{4}$ UPT Taman Hutan Raya Ngurah Rai, Dinas Kehutanan Provinsi Bali, Indonesia \\ ${ }^{5}$ Institute of Multidisciplinary Research for Advanced Material, Tohoku University, 2-1-1 Katahira, Aoba-ku, Sendai, 980-8577, Japan
}

\begin{abstract}
Coastal plants are recognized to yield secondary metabolites including polyisoprenoid alcohols. Coastal plants have been shown to have biological and phytochemical activities. The present study reports the search for polyisoprenoids composition from flowers and fruits of selected coastal plants, Amorphophallus paeoniifolius, Guettarda speciosa, and Jatropha curcas. A two-dimensional thin layer chromatography (2D-TLC) was used to analyse the composition and occurrence of polyisoprenoid alcohols (polyprenols and dolichols) in coastal plants. The distribution of polyprenols and dolichols in the flowers and fruits were detected and classified into one type only, type-II. Type-II, having the presence of both polyprenols and dolichols, was found in all samples investigated: in the flowers and fruits of $A$. paeoniifolius, G. spiciosa, and J. curcas. It is interesting to note that no dominating dolichols over polyprenols (type-I) or predominance polyprenol over dolichols (type-III) detected in this study. The present study, therefore, suggested the diversity of polyisoprenoids in the generative tissues of tropical coastal plants.
\end{abstract}

\section{Introduction}

Indonesia has the most significant mangrove area global, which is 22.6 percent of the worldwide total, with the length of shoreline close to at 95,181 km [1]. Mangrove forests in Bali province primarily widespread in Tanjung Benoa and Forest Park Conservation Area Ngurah Rai, Nusa Lembongan, and National Park Bali Barat [2]. Mangrove species can be separated into true mangroves or exclusive species and mangrove associates also known as non-exclusive or coastal plants [3].

Mangrove plants along with coastal plants are important to yield secondary metabolites including polyisoprenoid alcohols [3-6]. Furthermore selected species, namely Amorphophallus paeoniifolius, Guettarda speciosa, and Jatropha curcas are common mangrove associates in Bali [2]. Phytopharmacological properties have been shown in A. paeoniifolius, G. speciosa, and $J$. curcas [7-9]. For example, the antioxidant activity of $A$. paeoniifolius correlated to phenolic content [10], antiseizure activities of G. speciosa [8], and antimetabolic constituents of $J$. curcas [9]. These studies suggested that these mangrove associates are regarded as medicinal values.

The existence of polyisoprenoids has been referred to various plant tissues either in vegetal: leaves and roots [3-6], and reproductive: flowers, fruits, and seeds [10-
11]. These studies divulged the universal distribution of polyisoprenoids in the plant kingdom. The pattern and spreading of polyisoprenoid in mangrove and coastal plants have been reported [3-6]. It is essential to understand the function of polyisoprenoid various type of tissues, the detail information on the composition and profile of polysioprenoids in generative organs mangroves are entirely required. Therefore present study aimed to investigate the polyisoprenoids (polyprenol and dolichol) pattern and composition from selected coastal plants namely $A$. paeoniifolius, G. speciosa, and $J$. curcas flowers and fruits to extend our forgoing works on the exploration of polyisoprenoid from coastal plants.

\section{Materials and methods}

\subsection{Chemicals}

A combination of dolichols $\left(\mathrm{C}_{90}-\mathrm{C}_{95}\right)$ and polyprenols $\left(\mathrm{C}_{90}-\mathrm{C}_{100}\right)$ standard compounds as hitherto reported [2] was used to recognise the polyisoprenoids in this study. The description of the family concerning polyprenols or dolichols was accomplished in at least three experiments. Silica gel 60 TLC glass plates and reversed-phase silica RP-18 HPTLC glass plates were obtained from Merck (Darmstadt, Germany). All of the other chemicals and

\footnotetext{
Corresponding author: m.basyuni@usu.ac.id
} 
solvents were of reagent grade.

\subsection{Plant materials}

The flowers and fruits of selected coastal plants, Amorphophallus paeoniifolius (Araceae), Guettarda speciosa (Rubiaceae), and Jatropha curcas (Euphorbiaceae) were collected from Forest Park Conservation Area Ngurah Rai, Bali, Indonesia, in June 2017. These coastal vegetation are naturally growing to direct sunlight. The mean temperature in the month of the collection was $30{ }^{\circ} \mathrm{C}$ with an ordinary humidity of $74 \%$. All of the fresh samples were maintained at $-30^{\circ} \mathrm{C}$ until used.

\subsection{Polyisoprenoid alcohols extraction}

A manual for the polyisoprenoids extraction was done as previously described [11-12]. The flowers and fruits were dehydrated at $65-70^{\circ} \mathrm{C}$ for two days. The withered organ $(5 \mathrm{~g}$ each) was powdered and submerged in $30 \mathrm{ml}$ of chloroform/methanol $(2 / 1, \mathrm{v} / \mathrm{v})$ solvent for two days. The lipid extract of flowers and fruits was treated by saponification at $75^{\circ} \mathrm{C}$ for one day in $50 \%$ ethanol having $2 \mathrm{M} \mathrm{KOH}$. The nonsaponifiable lipids of every tissue sample put in with hexane, and the organic solvent was dispersed and re-dissolved in hexane as earlier described [4]. The fruit $(100-150 \mathrm{mg})$ and flower $(150-$ $200 \mathrm{mg}$ ) extracts were used to each TLC plate.

\subsection{Polyisoprenoids were analysis by two- dimensional thin layer chromatography (2D- TLC)}

First-dimensional TLC (1D-TLC) was executed for nearby one $\mathrm{h}$ on a silica gel glass plate $(20 \times 3 \mathrm{~cm})$ with a toluene-ethyl acetate $(9: 1)$ solvent as earlier defined [11]. The longitudinal brink of the 1D-TLC plate was 1 $\mathrm{cm}$ in width, and the accumulation area of a reversedphase C-18 TLC was fix by two magnetic bars $(4.0 \times 1.1$ $\times 0.8 \mathrm{~cm}$ ) fronting each gel stage. The bound TLC plate was then developed vertically to the $1 \mathrm{D}$ to transfer polyprenol or dolichol to the aggregation zone of the reversed-phase TLC plate.

The 2D-TLC was accomplished with acetone as the solvent for roughly $50 \mathrm{~min}$. The marks of plants extract combinations, and standard mixes are dispersed and being generated by 2D-TLC was then recognised and visualised with iodine vapour. The enhanced chromatographic imaged and alphanumerically scanned with a Canon E-470 series printer. The polyisoprenoid family was defined by the association of movement on TLC with those of specific standards of dolichol or polyprenol that were implemented in the 2D improvement. The polyprenols and dolichols that were traced on RP-18 HPTLC plates were measured with dolichol and polyprenol specifications as criterions.

\section{Results and discussion}

\subsection{Composition and profile of polyisoprenoids in selected coastal plants}

The selected coastal plants, namely $A$. paeoniifolius, $G$. spiciosa, and $J$. curcas for searching the long-chain polyisoprenoids was investigated by 2D-TLC [3]. Polyisoprenoids of different chain-lengths were divided into polyprenols and dolichols. Tables 1-2 accumulate the analytical results of the spreading of the polyprenols and dolichols with the carbon-chain lengths particular for very species.

TL content of coastal grasses flowers and stems ranged 533 to 888 and 582 to $640 \mathrm{mg} / \mathrm{g} \mathrm{dw}$, respectively (Table 1). The quantity of PI was highest in G. speciosa flowers $(121 \mathrm{mg} / \mathrm{g} \mathrm{dw})$ and A. paeoniifolius fruits (12 $\mathrm{mg} / \mathrm{g} \mathrm{dw})$. The lowes content of PI was in the flowers of A. paeoniifolius $(45 \mathrm{mg} / \mathrm{g} \mathrm{dw})$ and the fruits of $\mathrm{J}$. curcas $(8.3 \mathrm{mg} / \mathrm{g} \mathrm{dw})$ (Table 1).

The comparable results on TL and PI contents of this study were also have been earlier well agreed for Nephellium lappaceum fruits and flowers [11] and Hevea brasiliensis flowers [13]. The TL and PI concentrations in the coastal presented in this study were relatively higher than those shown from major and minor components of mangrove plants [3-5], fruit shell and fruit mesocarp of oil palm [12], and flowers and fruits of Philesia magellanica [14] and Fuchsia magellanica flowers [14]. These studies suggested the diversity of polyisoprenoid in plant reproductive tissues.

\subsection{Polyisoprenoid analyzed by 2D-TLC}

The spreading of polyprenols and dolichols in the roots were detected and classified into one group only. TypeII, which has the existence of both polyprenols and dolichols, was found all samples (Fig. 1, Table 2). No detected of group-I, which having to dominate dolichol over polyprenol and group-III, which shows the dominance of polyprenol over dolichol.

It is noteworthy that the presence of both polyprenols and dolichols in the flowers and fruits of selected coastal plants indicated the similar profile of $N$. lappaceum fruits [11], hybrid tenara of Elaeis guineensis fruit mesocarp and fruit shell from Lame [12].

This present study show opposite result on the plant fruits and fruits that was displaying only polyprenol pattern. It has been depicted that rubber plant flowers only contained $100 \%$ polyprenols $\left(\mathrm{C}_{80}-\mathrm{C}_{120}\right)$ [13]. These results were paralleled with previous findings on $P$. magellanica flowers and fruits having only polyprenols $\left(\mathrm{C}_{65}-\mathrm{C}_{110}\right)$ [14]. 
Table 1. Pattern of polyisoprenoids in selected coastal plants fruits and flowers.

\begin{tabular}{|c|c|c|c|c|c|c|c|c|c|c|c|}
\hline \multirow{2}{*}{ Species } & \multirow{2}{*}{ Tissue } & \multirow{2}{*}{$\begin{array}{c}\text { TL } \\
(\mathrm{mg} / \mathrm{g} \\
\mathrm{dw})\end{array}$} & \multirow[b]{2}{*}{$\begin{array}{c}\text { PI } \\
(\mathrm{mg} / \mathrm{g} \text { dw) }\end{array}$} & \multirow{2}{*}{$\begin{array}{c}\text { Pol } \\
\text { (mg/ } \\
\text { g) }\end{array}$} & \multirow{2}{*}{\begin{tabular}{|c} 
Dol \\
$(\mathrm{mg} /$ \\
$\mathrm{g})$ \\
\end{tabular}} & \multicolumn{3}{|c|}{$\%$ in $\mathrm{TL}$} & \multicolumn{2}{|c|}{$\%$ in $\mathbf{P I}$} & \multirow{2}{*}{ Type } \\
\hline & & & & & & PI & Pol & Dol & Pol & Dol & \\
\hline A. paeoniifolius & flower & $640.1 \pm 18.3$ & 45.0 & 18.6 & 26.4 & 7.0 & 2.1 & 4.1 & 41.3 & 58.7 & II \\
\hline G. speciosa & flower & $654.0 \pm 12.4$ & 121.1 & 67.8 & 53.3 & 18.5 & 10.3 & 8.1 & 56.0 & 44 & II \\
\hline J. curcas & flower & $582.6 \pm 10.9$ & 46.9 & 36.5 & 10.4 & 8.0 & 6.3 & 1.8 & 77.8 & 22.2 & II \\
\hline A. paeoniifolius & fruit & $880.9 \pm 13.1$ & 11.9 & 6.0 & 5.9 & 1.3 & 0.7 & 0.7 & 50.4 & 49.6 & II \\
\hline G. speciosa & fruit & $533.1 \pm 14.5$ & 8.9 & 2.9 & 6.0 & 1.7 & 0.5 & 1.1 & 32.6 & 67.4 & II \\
\hline J. curcas & fruit & $888.0 \pm 16.4$ & 8.3 & 3.7 & 4.6 & 0.9 & 0.4 & 0.5 & 44.6 & 55.4 & II \\
\hline
\end{tabular}

$\mathrm{nd}=$ not detected, $\mathrm{TL}=$ Total lipids, $\mathrm{PI}=$ Polyisoprenoids, $\mathrm{Pol}=$ Polyprenols, $\mathrm{Dol}=$ Dolichols, $\mathrm{dw}=$ dry weight. Data are expressed as mean $\pm \mathrm{SD}(n=3)$.

1

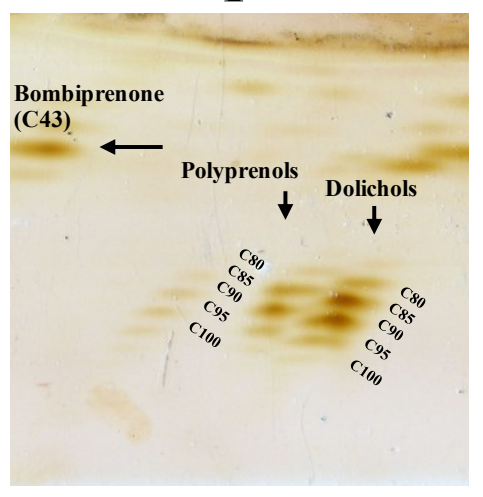

4

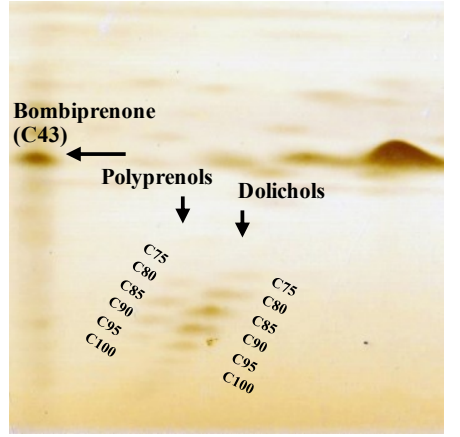

2

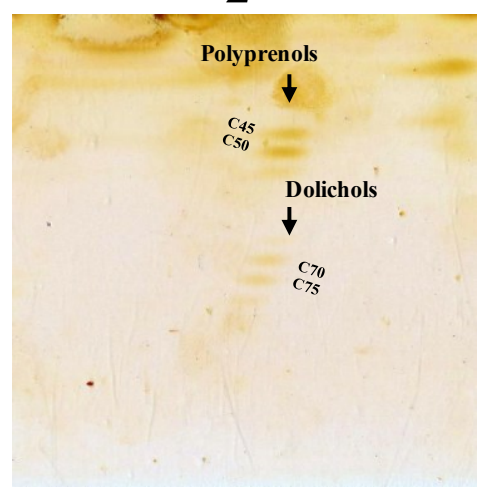

5

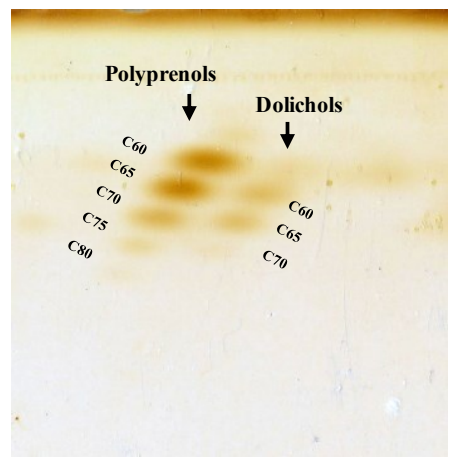

3

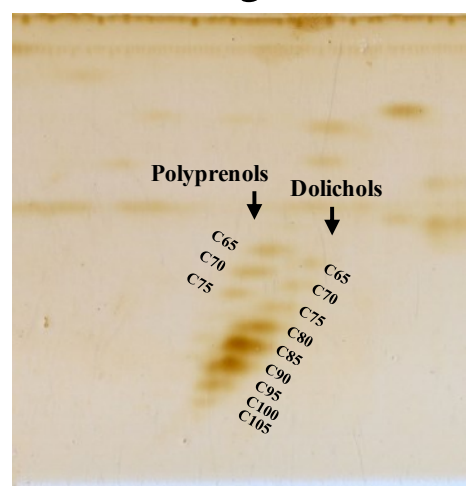

6

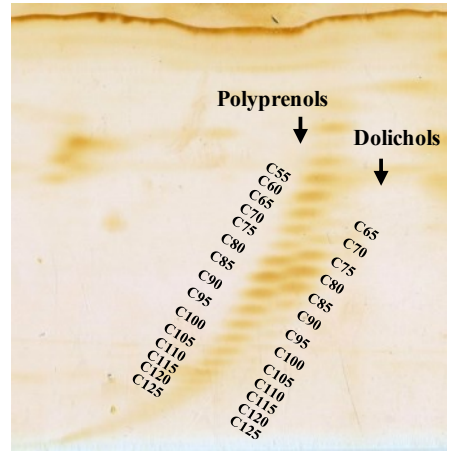

Fig 1. 2D-TLC chromatograms hexane extracts of polyisoprenoids from A. paeoniifolius fruits (1), G. speciosa fruits (2), J. curcas fruits (3), A. paeoniifolius flowers (4), G. speciosa flowers (5), and J. Curcas flowers (6).

A similar pattern was shown in F. magellanica flowers where polyprenols with chain length $\left(\mathrm{C}_{65}-\mathrm{C}_{130}\right)$ was described [14]. By contrast to this observation, in $N$. lappaceum flowers, the predominance of dolichol was observed [11]. These reports indicated difference polyisoprenoid pattern is modulated in plant generative organs, which may be influenced by tropical or subtropical climates [15]. Further investigation on other mangrove or coastal plant flowers and fruits may give to answer this interesting and important matter. 
Table 2. Carbon-chain lengths of polyprenol and dolichol of selected coastal plants.

\begin{tabular}{|c|c|c|c|c|}
\hline Species & Tissue & (C43) & Polyprenol & Dolichol \\
\hline A. paeoniifolius & Fruit & o & 80859095100 & 80859095100 \\
\hline G. speciosa & Fruit & & 4550 & 7075 \\
\hline J. curcas & Fruit & & 657075 & $\begin{array}{l}65707580859095100 \\
105110115\end{array}$ \\
\hline A. paeoniifolius & Flower & o & 7580859095100 & 7580859095100 \\
\hline G. speciosa & Flower & & 6065707580 & 606570 \\
\hline J. curcas & Flower & & $\begin{array}{l}556065707580859095100105110 \\
115120125\end{array}$ & $\begin{aligned} 65707580859095100 \\
105110115120125\end{aligned}$ \\
\hline
\end{tabular}

Furthermore, the physiological function of polyisoprenoids remains unclear. Recently it has been described that salinity changes the polyisoprenoid contents in four salt-secretor and non-salt-secretor mangroves [6]. The alteration of polyisoprenoids including in polyprenols and dolichols, as well. The content of polyisoprenoid also altered upon abiotic stress as well as with senescence has been shown $[5,13]$. In this context, polyisoprenoids are known to adapt to external stresses.

\section{Conclusion}

This study confirmed the presence of polyisoprenoids profile in the fruits and flowers of selected coastal grasses: the occurrence of both polyprenols and dolichols in all samples. The significant findings are showing the diversity of polyisoprenoids in the flower and fruit tissues even in the same species, suggesting the chemotaxonomic marker of polyisoprenoids in coastal plants for the potential use of phytopharmacological, medicinal, and biological properties.

This study was supported by an International Research Collaboration and Scientific Publication Grant 2018 and an Excellent Research of Higher Education Grant 2017 (No. 003/SP2H/LT/DRPM/IV/2017 to MB) from the Directorate for Research and Community Service, Ministry of Research, Technology and Higher Education, Republic of Indonesia.

\section{References}

1. C. Giri C, E. Ochieng, L.L. Tieszen, Z. Zhu, A. Singh, T. Loveland, J. Masek, N. Duke, Global Ecol. Biogeogr. 20, 154-159 (2011).

2. C. Kusmana, Mangrove Ecosystems of Asia Springer New York, 37-60 (2014).

3. M. Basyuni, R. Wati, H. Sagami, Sumardi, S. Baba S, H. Oku, Biodiversitas 19, 1-11 (2018).

4. M. Basyuni, H. Sagami, S. Baba, H. Oku, Dendrobiology 78, 18-31 (2017).

5. M. Basyuni, H. Sagami, S. Baba, H. Iwasaki, H. Oku, Dendrobiology 75, 167-175 (2016).
6. M. Basyuni, H. Sagami, S. Baba, L.A.P. Putri, R. Wati, H. Oku, HAYATI J. Biosci. 24, 206-214 (2017).

7. Y.N. Dey, S. Ota, N. Srikanth, M. Jamal, M. Wanjari, Ayu, 33, 27-32 (2012).

8. S. Arumugam, A. Palanivelu, G. Retnasamy, D. Ramaiyan, Iran. J. Pharmacol. Ther. 8, 73-76 (2009).

9. J. Martinez-Herrera, P. Siddhuraju, G. Francis, G. Davila-Ortiz, K. Becker, Food Chem. 96, 80-89 (2006).

10. J. Angayarkanni, K.M. Ramkumar, U. Priyadharshini, P. Ravendran, Pharm. Biol. 48, 659665 (2010).

11. M. Basyuni and R. Wati, IOP Conf. Ser.: Earth Environ. Sci. 101, 012001 (2017).

12. D. Arifiyanto, M. Basyuni, Sumardi, L.A.P. Putri, E.S. Siregar, I. Risnasari and I. Syahputra, Biodiversitas, 18, 1487-1492 (2017).

13. S. Tateyama, R. Wititsuwannakul, D. Wititsuwannakul D, H. Sagami H and K. Ogura, Phytochemistry, 51, 11-15 (1999).

14. K.A. Strzałka, R.E. Szymańska, E. Świeżewska, K.A. Skorupińska-Tudek, M.A. Suwalsky, Acta Biol Cracoviensia Ser. Bot., 51, 39-44 (2009).

15. M. Basyuni, R. Wati, J. Phys.: Conf. Ser., 801, 012011 (2017). 